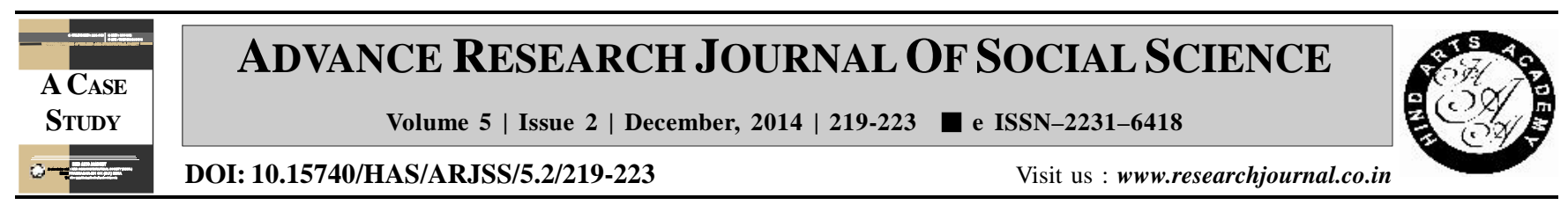

\title{
Knowledge level of the farmers regarding improved cultivation practices of Kharif jowar
}

\author{
R.H. Deshmukh, R.P. Kadam* and S.D. Bhandari
}

Department of Extension Education, College of Agriculture, Vasantrao Naik Marathwada Krishi Vidyapeeth, PARBHANI (M.S.) INDIA

\section{ARTICLE INFO :}

$\begin{array}{lll}\text { Received } & : & 17.06 .2014 \\ \text { Accepted } & : & 19.11 .2014\end{array}$

KEY WORDS :

Jowar, Knowledge level, Personal and Socio-economic characteristics

HOW TO CITE THIS ARTICLE:

Deshmukh, R.H., Kadam, R.P. and Bhandari, S.D. (2014). Knowledge level of the farmers regarding improved cultivation practices of Kharif jowar. Adv. Res. J. Soc. Sci., 5 (2) : 219-223.

*Author for correspondence

\begin{abstract}
The present study was conducted mainly with objective to study the knowledge and adoption of improved cultivation practices of Kharif jowar by farmers in Nanded district. The observations were made to know the maximum area under Kharif jowar and production of Kharifjowar under cultivation. Twelve villages were selected having larger area under cultivation of Kharif jowar in Nanded district. From each selected taluka, four villages were selected on the basis of maximum area and production under Kharif jowar cultivation. From each village ten respondents were selected randomly, who were having cultivated area under Kharif jowar. Thus, 120 respondents were selected. It was noticed that majority of the respondents had medium farming experience, educated upto Secondary School level, medium land holding, medium annual income, joint family structure, low level of social participation, medium risk preference, medium source of information, medium economic motivation, medium market orientation, medium level of knowledge. Majority farmers had knowledge about ploughing and harrowing, requirement of manuring/ha, suitable soil for cultivation, seed rate, improved variety of seed, sowing time, application of NPK fertilizers doses, weeding operation, protective irrigations, integrated pest and disease management practices and proper harvesting time. Correlation co-efficient ( $r$ ) showed that the independent variables namely, farming experience, education, risk preference, economic motivation, were positively and significantly related with the level of knowledge of improved cultivation practices of Kharif jowar, whereas land holding, annual income, family type, social participation, source of information and market orientation were having non-significantly relationship with knowledge of the farmers about improved cultivation practices of Kharif jowar.
\end{abstract}

